\title{
Nodulated White Lupin Plants Growing in Contaminated Soils Accumulate Unusually High Mercury Concentrations in Their Nodules, Roots and Especially Cluster Roots
}

\author{
Miguel A. Quiñones*(D), Susana Fajardo, Mercedes Fernández-Pascual, M. Mercedes Lucas (D) and José J. Pueyo*(D) \\ Department of Soil, Plant and Environmental Quality, Institute of Agricultural Sciences, ICA-CSIC, Serrano, \\ 115-bis, 28006 Madrid, Spain; sfajardo@ica.csic.es (S.F.); mfernandezp@ica.csic.es (M.F.-P.); \\ mlucas@ica.csic.es (M.M.L.) \\ * Correspondence: ma.quinones@csic.es (M.A.Q.); jj.pueyo@csic.es (J.J.P.)
}

check for updates

Citation: Quiñones, M.A.; Fajardo, S.; Fernández-Pascual, M.; Lucas, M.M.; Pueyo, J.J. Nodulated White Lupin Plants Growing in Contaminated Soils Accumulate Unusually High Mercury Concentrations in Their Nodules, Roots and Especially Cluster Roots Horticulturae 2021, 7, 302. https:/ / doi.org/10.3390/horticulturae7090302

Academic Editors: Luisa

Louro Martins and Miguel

Pedro Mourato

Received: 17 August 2021

Accepted: 7 September 2021

Published: 9 September 2021

Publisher's Note: MDPI stays neutral with regard to jurisdictional claims in published maps and institutional affiliations.

Copyright: (c) 2021 by the authors. Licensee MDPI, Basel, Switzerland. This article is an open access article distributed under the terms and conditions of the Creative Commons Attribution (CC BY) license (https:// creativecommons.org/licenses/by/ $4.0 /)$.
Abstract: Two white lupin (Lupinus albus L.) cultivars were tested for their capacity to accumulate mercury when grown in $\mathrm{Hg}$-contaminated soils. Plants inoculated with a Bradyrhizobium canariense $\mathrm{Hg}$-tolerant strain or non-inoculated were grown in two highly Hg-contaminated soils. All plants were nodulated and presented a large number of cluster roots. They accumulated up to $600 \mu \mathrm{g} \mathrm{Hg} \mathrm{g}^{-1}$ DW in nodules, $1400 \mu \mathrm{g} \mathrm{Hg} \mathrm{g}^{-1} \mathrm{DW}$ in roots and $2550 \mu \mathrm{g} \mathrm{Hg} \mathrm{g}^{-1} \mathrm{DW}$ in cluster roots. Soil, and not cultivar or inoculation, was accountable for statistically significant differences. No $\mathrm{Hg}$ translocation to leaves or seeds took place. Inoculated L. albus cv. G1 plants were grown hydroponically under cluster root-promoting conditions in the presence of $\mathrm{Hg}$. They accumulated about $500 \mu \mathrm{g} \mathrm{Hg} \mathrm{g}^{-1} \mathrm{DW}$ in nodules and roots and up to $1300 \mathrm{\mu g} \mathrm{Hg} \mathrm{g}^{-1} \mathrm{DW}$ in cluster roots. No translocation to the aerial parts occurred. Bioaccumulation factors were also extremely high, especially in soils and particularly in cluster roots. To our knowledge, $\mathrm{Hg}$ accumulation in cluster roots has not been reported to date. Our results suggest that inoculated white lupin might represent a powerful phytoremediation tool through rhizosequestration of $\mathrm{Hg}$ in contaminated soils. Potential uptake and immobilization mechanisms are discussed.

Keywords: Lupinus albus; lupin; Bradyrhizobium canariense; rhizobia; mercury; Hg; cluster roots; nodule; phytoremediation; rhizosequestration

\section{Introduction}

Environmental pollution is one of the most critical problems affecting society in the 21st century. The loss of air quality, water resources and available soil is drastically affecting food security and public health [1,2]. Many studies have demonstrated that heavy metals and metalloids such as mercury $(\mathrm{Hg})$, arsenic $(\mathrm{As})$, lead $(\mathrm{Pb})$, cadmium $(\mathrm{Cd})$, zinc $(\mathrm{Zn})$, nickel $(\mathrm{Ni})$ and chromium $(\mathrm{Cr})$ are present in plants of agronomic interest and pose major environmental risks, and present human health implications [3]. Heavy metals are present in soil either as free or bioavailable ions (soluble metal salts), or as insoluble or partially soluble compounds (oxides, carbonates and hydroxides). Many environmental or human factors can influence the toxicity, mobilization, migration or accumulation of heavy metals by changing soil structure, its physicochemical properties or microbial diversity [4]. Among heavy metals, $\mathrm{Hg}$ is considered one of the most toxic elements, with highly adverse effects on soil biological activity and plant metabolism, even at low concentrations [5-7]. Once deposited in the soil, it is retained mainly by organic matter, iron and manganese oxides and clay minerals [8], and is strongly bound to soil constituents, resulting in low availability and mobility [9]. However, under certain conditions mobilization can occur, where both $\mathrm{pH}$ and chloride concentrations in the soil solution are favorable for complex formation [10]. 
The Almadén Mining District in Ciudad Real, Spain comprises the largest natural concentration of $\mathrm{Hg}$ in the world. Consequently, it is also one of the most $\mathrm{Hg}$ contaminated areas, as a result of both, natural occurrence and anthropogenic activities [11,12]. When searching for appropriate alternative uses for local soils, agricultural activities stand out as an environmentally friendly and potentially cost-effective option to mining in this area [13]. Regrettably, the soils affected by mining activity are generally low in nutrients and organic matter.

Legumes are particularly well suited to colonize contaminated or nutrient-deprived soils [14]. Most species develop nitrogen-fixing nodules by establishing symbiosis with soil rhizobia. The inclusion of nitrogen-fixing plants appears to be a good strategy for stabilizing vegetation and facilitating ecosystem development by increasing the nitrogen content of the soils and boosting vegetation cover [15], but it is also necessary to address the problem of how the $\mathrm{Hg}$ present in the soil may affect the plants. Symbiosis confers legumes increased tolerance to various abiotic stresses, including heavy metal stress [16]. White lupin (Lupinus albus L.) is both an agronomic crop, since it provides seeds for food and feed, fodder and green manure, and a horticultural crop, as it is a good honey plant and an attractive annual ornamental [17]. Lupin seeds have an extremely high protein content; thus, lupin is considered as an excellent protein crop capable of promoting socioeconomic growth and environmental benefits to the areas where it is cultivated $[18,19]$. Lupin is a legume particularly well suited for growth in marginal soils because not only is it capable of forming nitrogen-fixing nodules in symbiosis with rhizobia, but it is also capable of developing cluster or proteoid roots that promote P mobilization [16]. Symbiosis is established with bacteria that most often belong to the Bradyrhizobium genus, and occasionally to other genera [20], in a unique process leading to the formation of lupinoid nodules [21,22]. Proteoid roots were observed by Engler over 100 years ago and later defined as dense clusters of rootlets of limited growth [23]. Currently, the more general term, cluster roots, proposed by Lamont [24] is recommended. Cluster roots are specialized roots capable of mobilizing nutrients $(\mathrm{P}, \mathrm{Fe}, \mathrm{Zn}, \mathrm{Mn})$ by inducing chemical changes in the rhizosphere $[25,26]$. Cluster roots appear under conditions of low $\mathrm{P}$ and, at least in some species, low $\mathrm{Fe}[27,28]$. They excrete carboxylates (mainly citrate and malate), protons and phenolics, generating changes in $\mathrm{pH}$ or redox potential in the rhizosphere that mobilize nutrients [29,30]. Furthermore, cluster roots mobilize $\mathrm{P}$ by exuding acid phosphatases [31] and improve $\mathrm{P}$ uptake by inducing a high-affinity $\mathrm{P}$ transport system [32]. The morphology of cluster roots has evolved towards a maximization of the surface-volume ratio. This increase in root exudation surface enhances nutrient mobilization in the rhizosphere [26,30]. Nodules and cluster roots have major roles in lupin $\mathrm{N}$ and $\mathrm{P}$ metabolisms, respectively, but there are interactive regulation pathways between both organs that interlink $\mathrm{N}$ and $\mathrm{P}$ recycling [33].

There are many studies showing how Hg impairs plant development, but not so many specifically addressing the effects of this heavy metal on nodulated nitrogen-fixing legumes or their Hg-accumulation capacity. Retama sphaerocarpa plants growing near Almadén translocate small amounts of $\mathrm{Hg}$ to the aerial parts [9]. In Vigna radiata, increasing $\mathrm{Hg}$ concentrations in the substrate produced decreases in leaf area, root and shoot length, number and size of nodules and chlorophyll and leghemoglobin contents [34]. L. albus plants in symbiosis with a $\mathrm{Hg}$-sensitive Bradyrhizobium canariense strain exposed to increasing concentrations of $\mathrm{Hg}$ in hydroponic culture endured significant declines in aerial biomass, chlorophylls and xanthophylls contents, photosynthetic efficiency, stomatal conductance, nodule number and weight and nitrogenase activity [35]. Furthermore, drastic tissue and cellular alterations were described in both leaves and nodules of these plants that were directly related to the presence of $\mathrm{Hg}$ in the substrate [36]. Conversely, when L. albus plants were inoculated with a Hg-tolerant $B$. canariense strain, none of the above-described Hg-induced damages were observed, and the plants could be considered tolerant to this heavy metal, were able to fix nitrogen and grow normally, and accumulated substantial $\mathrm{Hg}$ amounts in their roots and nodules $[35,36]$. Besides, the L. albus-B. canariense symbiosis has 
been proven tolerant to different abiotic stresses such as nitrate [37], salt [38], herbicides [16] or heavy metals such as $\mathrm{Zn} \mathrm{[39],} \mathrm{Cd} \mathrm{[40]} \mathrm{and} \mathrm{Cu} \mathrm{[41].} \mathrm{In} \mathrm{light} \mathrm{of} \mathrm{these} \mathrm{reported} \mathrm{features,} \mathrm{it}$ seemed reasonable to consider the L. albus-B. canariense symbiotic system a good candidate for the phytoremediation of Hg-contaminated soils. To our knowledge, the possible role of cluster roots in heavy metal phytoremediation has not been investigated.

Phytoremediation is the removal or destruction of contaminants by plants [42]. Plants suitable for phytoremediation of heavy metals should have a fast growth, high biomass and widespread roots, be easily harvested and, naturally, be able to tolerate and accumulate those heavy metals [43]. Plants can achieve phytoremediation through different approaches such as phytostabilization, phytovolatilization, phytoextraction, rhizofiltration or phytodegradation, and all of them have advantages and disadvantages [44]. Rhizoremediation is the removal of heavy metals from the environment by the roots of plants in association with the microorganisms present in the rhizosphere [44], and rhizostabilization is the immobilization of contaminants by absorption, precipitation or complexation, therefore reducing their bioavailability and distribution in the wildlife food chain [45]. Phytosequestration is the ability of plants to sequester contaminants in the root zone, and it is used as a synonym of rhizostabilization or phytostabilization in plant roots. The current definition of a hyperaccumulator is a plant capable of taking up a metal from the soil, translocating it to the aerial parts and concentrating it in the leaves at a concentration larger than that in the soil [46-49]. Even though more than 700 plant species have been described as hyperaccumulators of heavy metals, very few have proven utility in the phytoremediation of contaminated soils since most of them have a high metal specificity (they only accumulate one metal) and are slow-growing, low biomass-producing species [50,51]. To date, no Hg hyperaccumulator species have been identified, although considerable progress has been made in identifying plant species that can grow on Hg-contaminated soil [52]. Thus, Hg rhizostabilization/phytosequestration might represent more feasible phytoremediation strategies to reduce environmental and health risks associated to the presence of $\mathrm{Hg}$ in soils.

The aims of this study were to analyze the ability of L. albus cvs. N1 and G1 plants in symbiosis with $\mathrm{Hg}$ - tolerant $B$. canariense rhizobia to grow in $\mathrm{Hg}$-contaminated soils and hydroponic conditions, to assess their capacity to accumulate $\mathrm{Hg}$ in their underground organs (root, nodules and cluster roots) and to evaluate their phytosequestration potential.

\section{Materials and Methods}

\subsection{Soils}

Two soils were collected to carry out this study from the Almadén Mining District, located in South-Central Spain (Ciudad Real). One of them was collected in Almadenejos $(\mathrm{AH})$, a heavily $\mathrm{Hg}$-contaminated site where the furnaces used to extract $\mathrm{Hg}$ from cinnabar ore used to be located (UTM 30N: N351189; E4289382), and the second one (LC) was obtained from the Las Cuevas mine (UTM 30N: N347016; E4298281). The soils were cleaned, sieved and stored until use. Soil $\mathrm{pH}$, organic matter content and elemental analysis (except for $\mathrm{Hg}$ ) were performed at the Soil, Plant and Water Analysis service at the ICA-CSIC in Madrid, Spain. Samples were digested in nitric/perchloric acid, cooled, resuspended, filtered and analyzed by inductively coupled plasma-atomic emission spectrometry with a Perkin Elmer Optima 4300 DV spectrometer (Waltham, MA, USA). Soil Hg content was analyzed at the Heavy Metals Biogeochemistry Laboratory of the School of Mining and Industrial Engineering of Almadén (Ciudad Real, Spain). Samples were stove-dried, sieved, mortar-ground and analyzed by high-frequency modulation atomic absorption spectrometry with Zeeman effect (ZAAS-HFM), using a Lumex RA-915+ device with a pyrolysis attachment (Mission, BC, Canada). Soil analyses are shown in Table 1. For the experiments, both soils were mixed in equal parts with vermiculite to avoid compaction. 
Table 1. Characterization of Almadenejos (AH) and Las Cuevas (LC) soils.

\begin{tabular}{|c|c|c|c|c|c|c|c|c|}
\hline Soil & $\mathrm{pH}$ & $\begin{array}{c}\text { Organic } \\
\text { Matter (\%) }\end{array}$ & C (\%) & N (\%) & $\begin{array}{l}\text { Bioavailable } \\
\text { Fe }\left(\mu g^{-1}\right)\end{array}$ & $\mathbf{P}\left(\mu g g^{-1}\right)$ & $\begin{array}{l}\text { Total Hg } \\
\left(\mu g^{-1}\right)\end{array}$ & $\begin{array}{l}\text { Bioavailable } \\
\mathrm{Hg}\left(\mu \mathrm{g} \mathrm{g}^{-1}\right)\end{array}$ \\
\hline $\mathrm{AH}$ & 6.87 & 8.59 & 3.33 & 0.26 & 106.3 & 11.2 & 21,845 & 2.69 \\
\hline LC & 5.09 & 9.85 & 3.82 & 0.35 & 158.9 & 3.6 & 2622 & 0.82 \\
\hline
\end{tabular}

\subsection{Plant Material, Inoculation and Growth in Hg-Contaminated Soils}

White lupin cultivars (Lupinus albus L. cv. G1 and cv. N1) were selected after lupin germplasm screening identified them as Hg-tolerant. The screening method used the relative root growth at the seedling stage as an indicator of heavy metal tolerance, and was adapted for lupin seedlings from a previously described system used in the identification of $\mathrm{Hg}$ - and Cd-tolerant Medicago truncatula cultivars [53,54]. Seeds were surface sterilized by submersion in $1 \% \mathrm{HgCl}_{2}$ for $5 \mathrm{~min}$ and then washed thoroughly with sterile distilled water. Forty-eight $1 \mathrm{~L}$ plastic containers were filled with Almadenejos soil-vermiculite mix and 48 containers with Las Cuevas soil mix. Each group of 48 pots was divided into two groups of 24 in which seeds (one per pot) of cultivars G1 or N1 were sown.

One half of the seeds were inoculated with Bradyrhizobium canariense $\mathrm{Hg}$-tolerant strain L-7AH, isolated from Almadenejos (Ciudad Real, Spain) and previously characterized [55]. Each seed was inoculated twice, once at the time of sowing and again one week later, with $1 \mathrm{~mL}$ of $B$. canariense cell suspension in exponential growth phase $\left(\mathrm{OD}_{600}=0.8\right)$. The remaining half of the seeds were not inoculated in order to check for nodulation by native soil rhizobia, and to assess the effects of inoculation. Plants were grown in an openair shade for six weeks without any environmental control, so that growing conditions were as similar as possible to those in the field. All plants were watered three times a week with sterile distilled $\mathrm{H}_{2} \mathrm{O}$ and rotated periodically to avoid any location-induced effects. This assay was carried out twice between March and June in Madrid (Spain) with similar results. Data presented herein are from the experiment completed between May and June 2019.

\subsection{Cluster Root Promotion Conditions}

White lupin seeds (L. albus L. cv. G1) were surface sterilized. Forty 1 L plastic containers were filled with vermiculite and seeds were sown. Each seed was inoculated twice with $B$. canariense $\mathrm{L}-7 \mathrm{AH}$, as described above. The plants were grown in a growth chamber under a $14 \mathrm{~h}$ light $\left(23^{\circ} \mathrm{C}\right) / 10 \mathrm{~h}$ dark $\left(20^{\circ} \mathrm{C}\right)$ photoperiod for six weeks. Relative humidity was maintained between 50 and $80 \%$, and the light (provided by a combination of LEDs and incandescent lights) had a photon flux density around $500 \mu \mathrm{mol} \mathrm{m}^{-2} \mathrm{~s}^{-1}$ PAR. The plants were watered three times a week with a nitrogen-free nutrient solution modified from [56], containing (or not) $50 \mu \mathrm{M} \mathrm{HgCl}_{2}$. The modification consisted of removing any trace of $\mathrm{P}$ from the nutrient solution during the first three weeks of growth to induce the formation of cluster roots. During the three subsequent weeks, P was added to the nutrient solution at two different concentrations: $0.5 \mathrm{mM}$ (standard concentration) [56] and $0.05 \mathrm{mM}$. This experiment was repeated three times.

\subsection{Chlorophyll Content and Stomatal Conductance}

Chlorophyll content and stomatal conductance were measured at the end of the sixth week in the youngest fully expanded leaves of all plants using non-invasive techniques. Total chlorophylls were measured using a portable chlorophyll content meter from OptiSciences Inc. (Model CCM-200 plus) (Hudson, NH, USA). Stomatal conductance was measured using a portable steady-state porometer from Decagon Devices Inc. (Model SC-1) (Pullman, WA, USA). 


\subsection{Sample Collection}

Plants were harvested and aerial parts and roots were separated. Aerial parts were weighed, frozen in liquid $\mathrm{N}_{2}$ and stored at $-80{ }^{\circ} \mathrm{C}$ for later analyses. Prior to freezing, the youngest fully expanded leaves were collected to measure leaf area (two leaves per plant). Intact roots were used to measure nitrogenase activity. Later, roots were washed with tap water, brushed with a paintbrush (to remove all soil and vermiculite) and rinsed thoroughly with deionized water. Nodules and cluster roots were separated, counted, weighed, frozen in liquid $\mathrm{N}_{2}$ and stored at $-80^{\circ} \mathrm{C}$. The remaining roots were frozen in liquid $\mathrm{N}_{2}$ and stored at $-80^{\circ} \mathrm{C}$ for later analyses. Two or three plants per treatment were left to grow until pods and seeds could be collected for $\mathrm{Hg}$ content analysis.

\subsection{Leaf Area}

Two leaves per plant, i.e., 20 leaves per treatment, were scanned using an Epson Perfection V350 Photo scanner (Suwa, Japan). Images were processed using the ImageJ v.1.53 software (NIH, Bethesda, MD, USA) to obtain leaf areas.

\subsection{Nitrogenase Activity}

Nitrogenase was measured using the acetylene reduction assay [56]. Gas samples were collected and analyzed using a Perkin Elmer 8310 gas chromatograph (Norwalk, CT, USA) equipped with a Porapak $\mathrm{R}$ column and using $\mathrm{N}$ as carrier gas with a $50 \mathrm{~mL} \mathrm{~min}{ }^{-1}$ flow.

\subsection{Mercury Content}

Nodules, roots and cluster roots were washed thoroughly with tap and distilled water, sweeping with a paintbrush. After rinsing, they were oven dried at $60{ }^{\circ} \mathrm{C}$ for $48 \mathrm{~h}$. $\mathrm{Hg}$ content in plant tissues was determined by the Soil, Plant and Water Analysis service at the ICA-CSIC in Madrid using a Perkin Elmer AAnalyst 100 atomic absorption spectrometer (Waltham, MA, USA). Samples from leaves, nodules, roots, cluster roots and seeds were collected.

\subsection{Statistical Analyses}

Data were analyzed with the SPSS v27.0 software package (SPSS Inc., Chicago, IL, USA). For the experiments with Almadén soils, three-factor analysis of variance $(p \leq 0.05)$ was used to analyze the effect of fixed factors (soil, inoculation and cultivar) and their interactions on each measured variable. For the vermiculite experiments, two-factor analysis of variance $(p \leq 0.05)$ was used to analyze the effect of fixed factors (P concentration and presence/absence of $\mathrm{Hg}$ ) and their interactions on each variable were measured. Significant differences among treatments were separated by the least significant difference test or the Tukey B test $(p \leq 0.05)$.

\section{Results}

\subsection{White Lupin Plants Grew Normally in Hg-Contaminated Soils and Were Efficient in Nitrogen Fixation}

A noticeable difference between both soils in this study was their $\mathrm{pH}$, which was close to neutral in Almadenejos (AH) and quite acidic in Las Cuevas (LC) (Table 1). This might have important implications in terms of solubility of nutrients, as well as contaminants. Both soils were very rich in organic matter and had similar $\mathrm{C}$ and $\mathrm{N}$ contents. Both were quite poor in $\mathrm{P}$ and rich in $\mathrm{Fe}$. AH soil presented an extremely high $\mathrm{Hg}$ contamination level, which was about 10 times lower in the LC soil, but still quite high. Most of the $\mathrm{Hg}$ was in the form of cinnabar and was, therefore, not bioavailable to plants. The difference in bioavailable $\mathrm{Hg}$ between the two soils was not so large $(\times 3.3)$, probably because the acidic $\mathrm{pH}$ of the LC soil contributed to increase $\mathrm{Hg}$ bioavailability. For the rest of the analyzed elements $(\mathrm{Ca}, \mathrm{Mg}, \mathrm{Na}, \mathrm{K}, \mathrm{Mn}, \mathrm{Zn}, \mathrm{Al}, \mathrm{Cu}, \mathrm{Ni}$ and $\mathrm{Pb}$ ), no significant differences were found between both soils and, furthermore, the values were well below the contamination level (data not shown). 
Lupinus albus G1 and N1 plants, inoculated with B. canariense L-7AH or non-inoculated, and grown in a shade for 6 weeks in either soil presented essentially the same phenotype [57]. There were no significant differences in aerial part fresh weight or leaf area between both cultivars, grown in either soil, inoculated or not [57]. Furthermore, when additional parameters such as chlorophyll content or stomatal conductance were measured, no significant differences were found (Table S1, Figure 1).

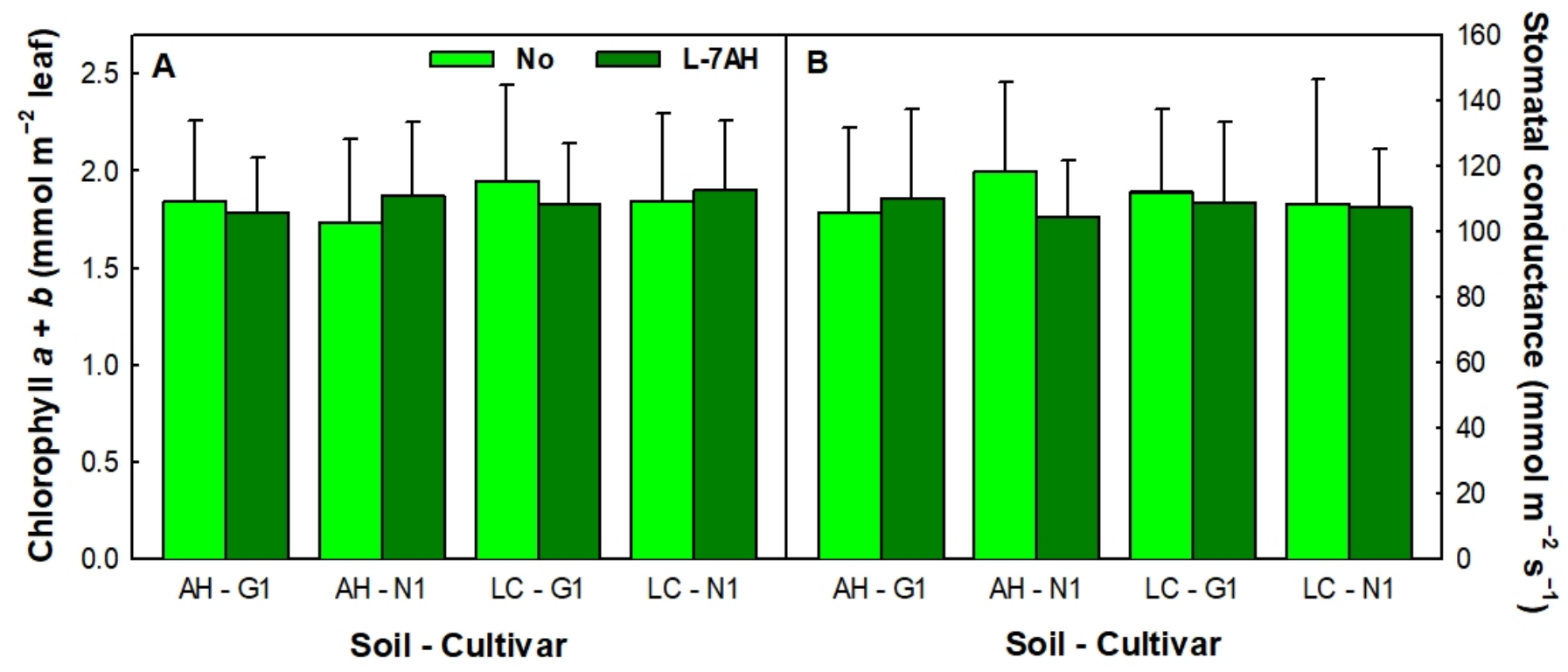

Figure 1. Chlorophyll content (A) and stomatal conductance (B) of L. albus G1 and N1 plants inoculated with B. canariense L-7AH on non-inoculated grown in soils from Almadenejos (AH) or Las Cuevas (LC). Total chlorophyll content and stomatal conductance were determined for the two youngest fully expanded leaves of 6-week-old plants grown in a shade. Data are means $\pm \mathrm{SD}, n=24$.

We have previously shown that both soils, $\mathrm{AH}$ and LC, contained native rhizobia able to nodulate L. albus G1 and N1 plants, and that plants inoculated with B. canariense L-7AH or non-inoculated presented significant differences in nodulation depending on the soil origin. Namely, plants grown in AH soil had $40-50$ nodules $(0.38-0.55 \mathrm{~g})$, while those grown in LC soil had around 20 nodules $(0.15-0.25 \mathrm{~g})$ per plant [57]. In the present work, no significant differences in specific nitrogenase activity (activity per gram of nodule) existed between nodules of L. albus cv. G1 or N1 plants inoculated with B. canariense L-7AH or non-inoculated and grown in AH or LC soils (Table S1, Figure 2A). The specific nitrogenase activity values obtained here were in the same range of those observed for L. albus plants inoculated with B. canariense L-7AH and grown in hydroponic conditions in the absence of $\mathrm{Hg}$ [35]. Nodule weight of plants grown in AH soil practically doubled that of plants grown in the LC soil [57]. Soil had an effect on the nitrogenase activity per plant (Table S1), which was approximately twice as high in plants grown in AH soil (Figure 2B). 


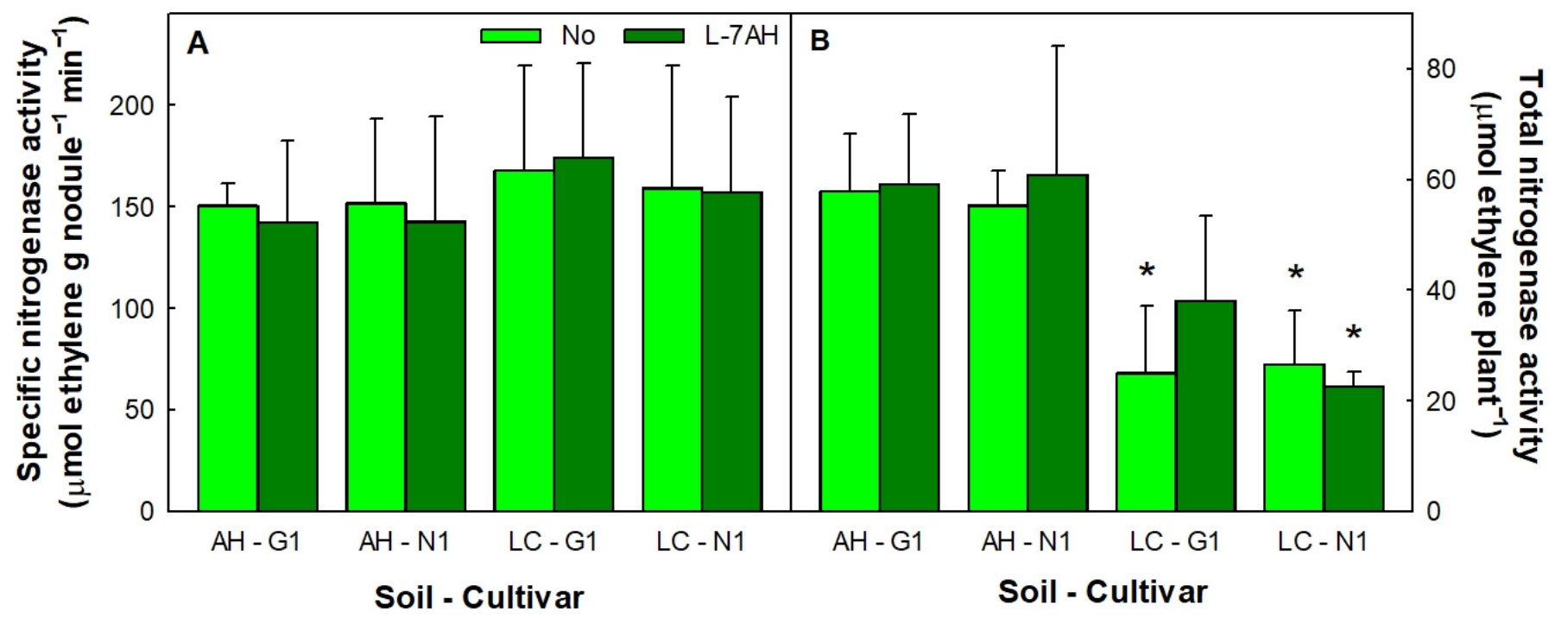

Figure 2. Specific nitrogenase activity (A) and total nitrogenase activity per plant (B) of nodules from L. albus G1 and N1 plants inoculated with B. canariense L-7AH or non-inoculated and grown in soils from Almadenejos (AH) or Las Cuevas (LC). Activity measurements were performed on roots of 6-week-old plants grown in shade. Data are means of four nitrogenase activity measurements \pm SD. Asterisks $\left(^{*}\right)$ indicate significant differences between soils.

\subsection{Cluster Root Occurrence Was High in Plants Grown in Hg-Contaminated AH and LC Soils}

When plants were collected, the presence of abundant root clusters in all plants could be observed. These cluster roots developed mostly in the secondary roots and were a darker shade of brown than the rest of the roots (Figure 3). The cluster roots were counted and weighed and the results are presented in Figure 4A,B. No significant differences were found in cluster root number between N1 and G1 plants, inoculated or not, grown in either soil (Table S1, Figure 4). Total root fresh weights showed a very large variability between plants; there were no significant differences between soils or cultivars and average whole root weights ranged from 6.75 to $7.85 \mathrm{~g}$. Most plants averaged 20-25 cluster roots with a minimum of 11 and a maximum of 41, but large differences between plants accounted for large standard deviations. It should be noted that when L. albus plants were inoculated with $B$. canariense L-7AH and grown in hydroponic conditions and watered with a standard nutrient solution, rich in $\mathrm{P}$, no cluster roots were formed (in rare occasions, one or two cluster roots could be observed in one isolated plant).

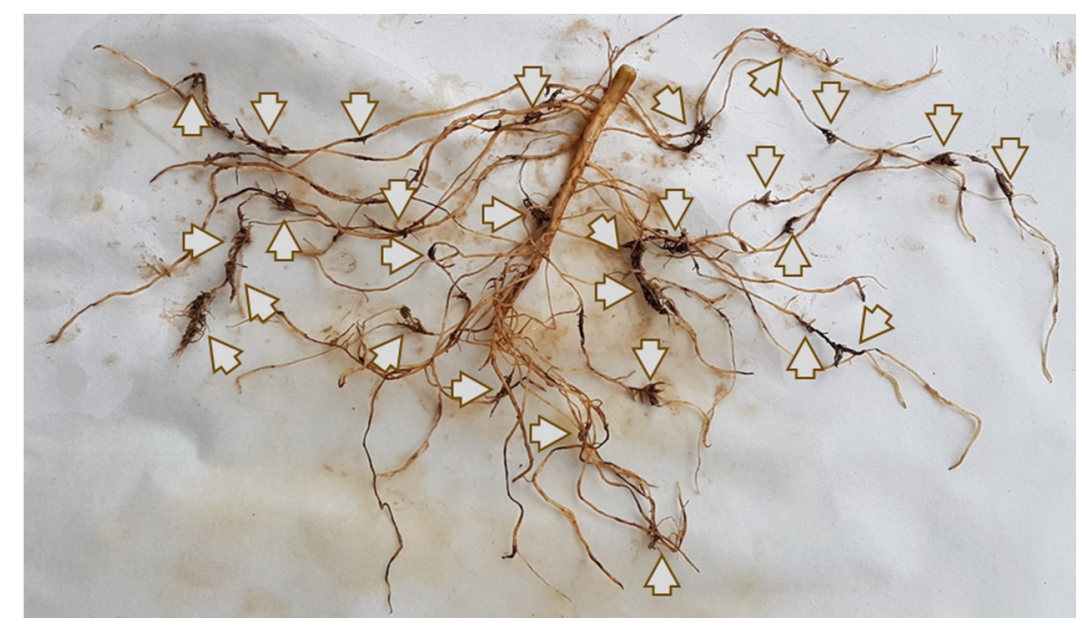

Figure 3. Root of a 6-week-old L. albus G1 plant inoculated with B. canariense L-7AH and grown in soil from Almadenejos. Arrows indicate cluster roots. 


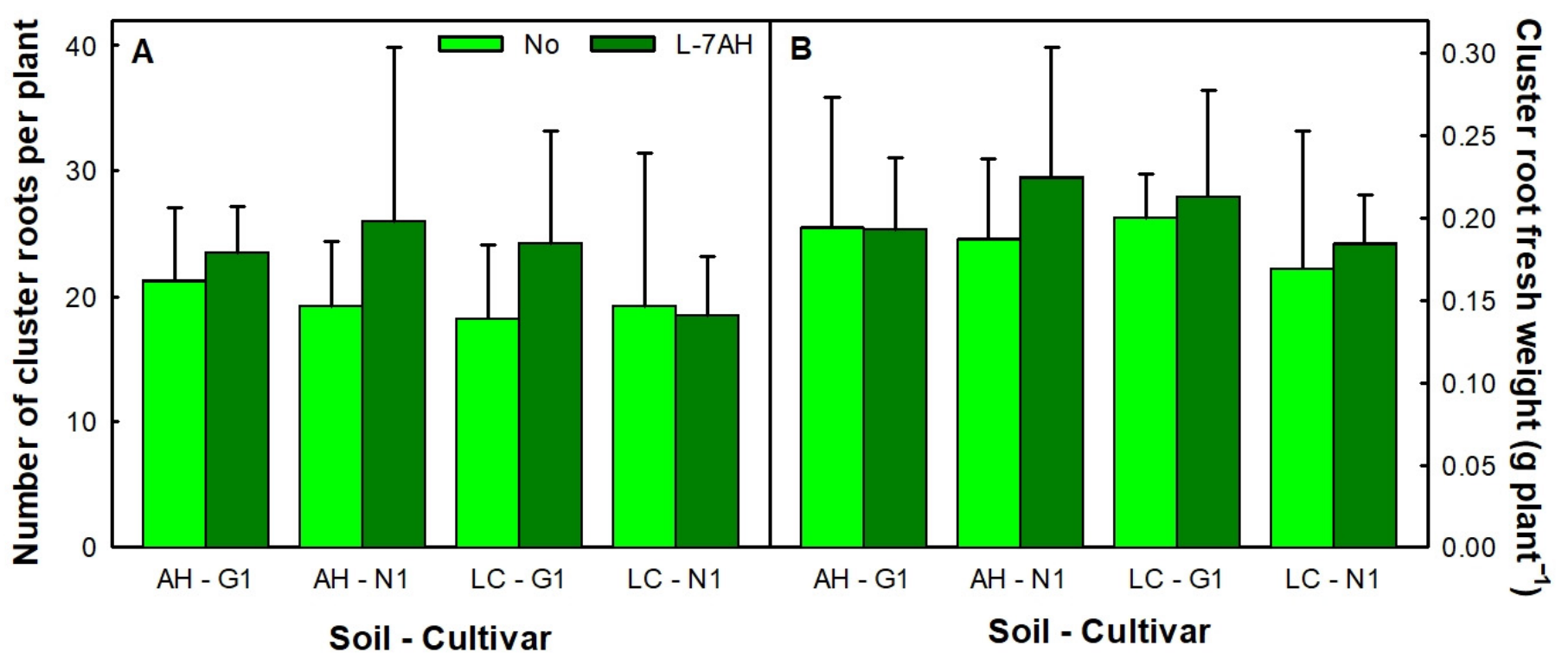

Figure 4. Number (A) and weight (B) of cluster roots per plant. L. albus G1 and N1 plants were inoculated with B. canariense L-7AH or non-inoculated and grown in Almadenejos (AH) or Las Cuevas (LC) soils. Means $(n=12) \pm$ SD are shown.

3.3. White Lupin Plants Grown in Hg-Contaminated Soils Accumulated Elevated Amounts of Hg in Nodules, Roots and Cluster Roots

Samples of leaves, nodules, roots, cluster roots and seeds were collected to determine their $\mathrm{Hg}$ content. No $\mathrm{Hg}$ could be detected in any leaves and seeds samples (detection limit $\left.1 \mathrm{ng} \mathrm{g}^{-1}\right)$. Conversely, nodules, roots and cluster roots accumulated large amounts of this heavy metal, and soil appeared to have a significant effect on $\mathrm{Hg}$ accumulation (Table S1, Figure 5).

Nodules from plants grown in AH soil accumulated around $600 \mu \mathrm{g} \mathrm{Hg} \mathrm{g} \mathrm{H}^{-1} \mathrm{dry}$ weight (DW) while plants grown in LC soil accumulated around $250-300 \mu \mathrm{g} \mathrm{Hg} \mathrm{g}^{-1} \mathrm{DW}$, independently of cultivar or inoculation. Differences between soils were only statistically significant for nodules of plants inoculated with B. canariense L-7AH. Hg accumulation in roots was significantly higher in plants grown in AH soil (1200-1400 $\left.\mathrm{g} \mathrm{Hg} \mathrm{g}^{-1} \mathrm{DW}\right)$ than in plants grown in LC soil (250-450 $\left.\mathrm{gg} \mathrm{Hg} \mathrm{g}^{-1} \mathrm{DW}\right)$, for both cultivars and inoculation treatments. Cluster roots accumulated the largest amounts of $\mathrm{Hg}$. Cluster roots of plants grown in AH soil accumulated 1850-2550 $\mu \mathrm{g} \mathrm{Hg} \mathrm{g}^{-1} \mathrm{DW}$, while cluster roots from plants grown in LC soil showed values between 800 and $1400 \mu \mathrm{g} \mathrm{Hg} \mathrm{g}{ }^{-1} \mathrm{DW}$. The differences between soils were statistically significant for both cultivars (Figure 5).

According to these results, translocation factors, $[\mathrm{Hg}]_{\text {leaves }} /[\mathrm{Hg}]_{\text {roots }}$, for plants from all treatments were zero. On the other hand, bioaccumulation factors or BAFs, $[\mathrm{Hg}]_{\text {tissue }} /$ bioavailable $[\mathrm{Hg}]_{\text {soil }}[58]$, were quite high for nodules, roots and cluster roots (Table 2). 


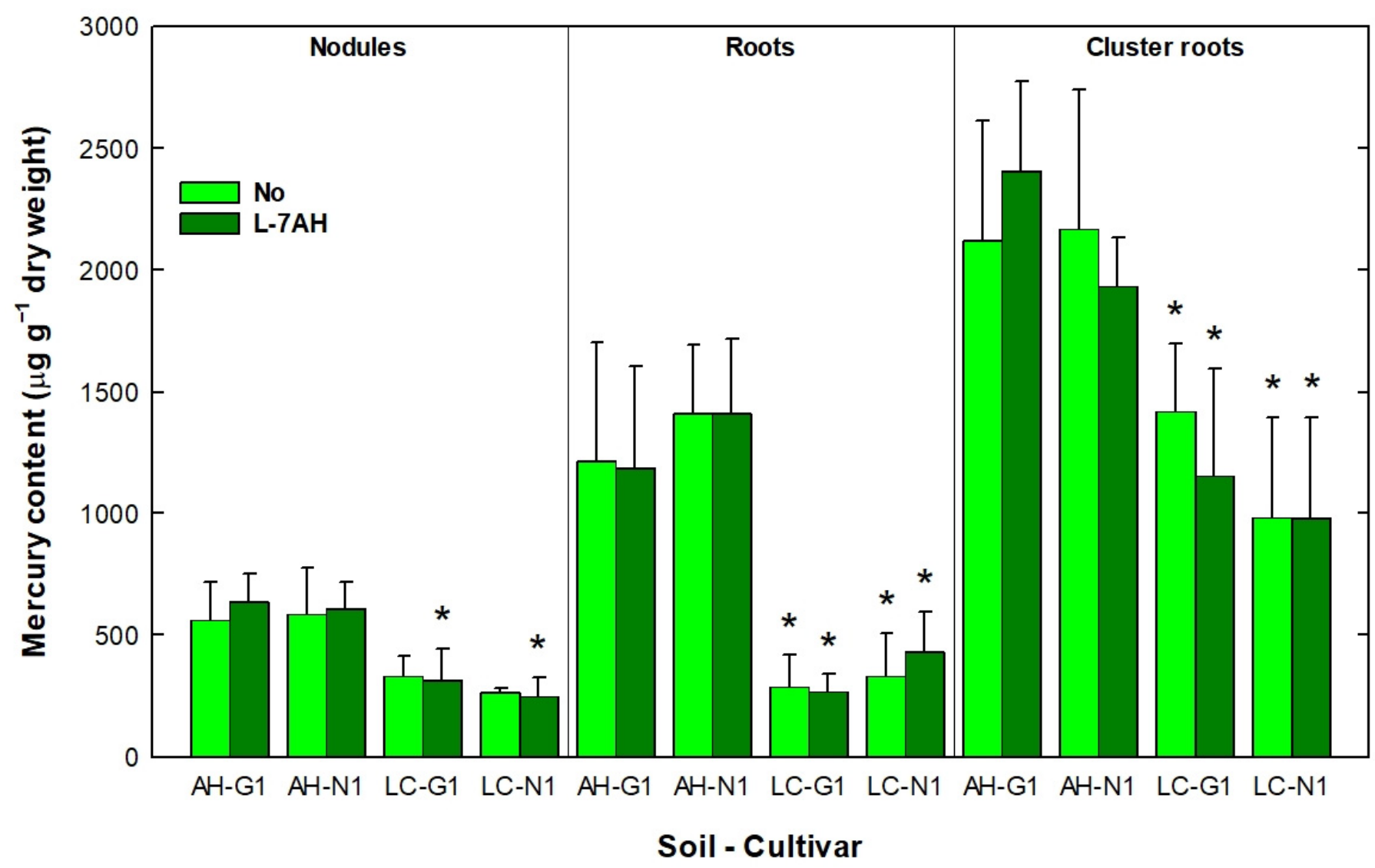

Figure 5. Mercury accumulation in nodules, roots and cluster roots of L. albus G1 or N1 plants inoculated with B. canariense L-7AH or non-inoculated and grown in soils from Almadenejos (AH) or Las Cuevas (LC). Means $(n=4) \pm$ SD are shown. Asterisks $\left({ }^{*}\right)$ indicate significant differences between soils.

Table 2. Mercury bioaccumulation factors (BAF) of nodules, roots and cluster roots of L. albus G1 and N1 plants grown in Almadenejos (AH) or Las Cuevas (LC) soils. BAFs were calculated as the ratio between the $\mathrm{Hg}$ concentration in the organ tissue and the bioavailable $\mathrm{Hg}$ concentration in the soil. Means for each cultivar (inoculated plus non-inoculated plants) \pm SD are shown. Asterisks $\left(^{*}\right)$ indicate significant differences between soils.

\begin{tabular}{ccccc}
\hline \multirow{2}{*}{ Tissue } & \multicolumn{2}{c}{ Almadenejos } & \multicolumn{2}{c}{ Las Cuevas } \\
\cline { 2 - 5 } & G1 & N1 & G1 & N1 \\
\hline Nodules & $443.5 \pm 98.1$ & $441.6 \pm 107.8$ & $787.2 \pm 215.7^{*}$ & $624.1 \pm 117.6^{*}$ \\
Roots & $889.2 \pm 313$ & $1046 \pm 202.1$ & $675.7 \pm 241.4$ & $927.0 \pm 406.5$ \\
Cluster roots & $1676.8 \pm 318.4$ & $1519 \pm 308.3$ & $3139.3 \pm 900.9 *$ & $2390.9 \pm 932.9 *$ \\
\hline
\end{tabular}

Inoculation did not have an effect on $\mathrm{Hg}$ accumulation (Table S1) and thus, BAFs were calculated for plants of the same cultivar (inoculated plus non-inoculated) and grown in the same soil. Since soils were mixed 1:1 with vermiculite (to avoid compaction), the bioavailable $\mathrm{Hg}$ concentration values utilized to calculate BAFs were $1.345 \mu \mathrm{g} \mathrm{g}^{-1}$ for AH soil and $0.41 \mu \mathrm{g} \mathrm{g}^{-1}$ for LC soil. The bioavailable $\mathrm{Hg}$ concentration in LC soil was much lower than that in AH soil, which led to higher BAF values for nodules and cluster roots. BAFs for roots were higher in $\mathrm{AH}$ soil, due to the high $\mathrm{Hg}$ accumulation values recorded for roots in this soil. Cluster roots presented the highest BAF values in both soils. Only nodules and cluster roots (from both cultivars) of plants grown in LC soil showed statistically significant higher BAF values than those calculated for plants grown in AH soil. 


\subsection{White Lupin Plants Grown Hydroponically under Cluster Root Promoting Conditions} Accumulate High Amounts of $\mathrm{Hg}$ in Nodules, Roots and Cluster Roots

In a previous work, we reported that $L$. albus plants inoculated with B. canariense $\mathrm{L}-7 \mathrm{AH}$ and exposed to $\mathrm{Hg}$ under hydroponic conditions were capable of accumulating up to $350-400 \mu \mathrm{g} \mathrm{Hg} \mathrm{g}^{-1} \mathrm{DW}$ in their roots and nodules [35]. Most plants did not develop cluster roots (occasionally, one or two cluster roots could be seen in an isolated plant) but as is common in hydroponic conditions, in rare occasions, one or two cluster roots could be observed in very few plants. We decided to study the effect of the presence of cluster roots on the $\mathrm{Hg}$ accumulation capacity of L. albus plants in symbiosis with B. canariense. The induction of cluster root formation in the L. albus-B. canariense system was achieved by depriving the plants of $\mathrm{P}$ during the first three weeks of development. Later, the plants were nurtured with two different $\mathrm{P}$ concentrations in the nutrient solution, that is, 0.05 $\mathrm{mM}$ (low) and $0.5 \mathrm{mM}$ (standard). This strategy led to the formation of cluster roots in all plants (Figure 6A,B). There were no significant differences in the number of cluster roots per plant between any of the different treatments (Table S2, Figure 6A,B). The different $P$ concentrations applied after the third week did not seem to have any effect on the number or weight of cluster roots per plant. The presence of $\mathrm{Hg}$ in the nutrient solution did not affect the number of cluster roots but caused a significant decrease in weight (measured as total weight per plant) (Figure 6B). Total root fresh weights were highly variable between plants, ranging from 8.0 to $9.8 \mathrm{~g}$ per plant. No significant differences between treatments were observed. Nodules, roots and cluster roots looked normal and similar to previously published pictures in different works, only darker in color when grown in the presence of $\mathrm{Hg}$.

The effect of growth under cluster root-promoting conditions on plant development parameters and nitrogen fixation was evaluated. Growth in the presence or absence of $\mathrm{Hg}$ had a significant effect on the plants' phenotypes. After 6 weeks, all plants presented similar size, their leaves had the characteristic dark green color, and they were starting to flower. However, both the aerial biomass and leaf area of plants grown with $0.5 \mathrm{mM} \mathrm{P}$ significantly decreased (Figure 6C,D). Total chlorophyll content and stomatal conductance were also measured, but no differences were found between treatments (data not shown). The number of nodules per plant decreased significantly in the presence of $\mathrm{Hg}$ (Figure 6E). However, $\mathrm{Hg}$ did not have an effect on the total weight of nodules per plant (Figure 6F), therefore nodules from plants grown in the presence of $\mathrm{Hg}$ were larger.

The healthy phenotype of the plants suggested that all of them could carry out $\mathrm{N}_{2}$ fixation independently of the treatment received. Total nitrogenase activity per plant decreased in the presence of $\mathrm{Hg}$, but the decrease was significant for cultivar N1 only (Figure 6G). No significant differences in specific nitrogenase activity between treatments were detected (Figure $6 \mathrm{H}$ ).

The ultimate purpose of this experiment was to determine whether plants grown hydroponically under cluster root-promoting conditions were capable of accumulating similarly large amounts of $\mathrm{Hg}$ in their nodules, roots and cluster roots, compared with plants grown in Hg-polluted soils. L. albus G1 plants inoculated with B. canariense L-7AH and watered with a nutrient solution containing $50 \mu \mathrm{M} \mathrm{HgCl}_{2}$ accumulated large $\mathrm{Hg}$ amounts in their underground organs but not in their leaves (Figure 7). Nodules and roots accumulated considerably similar amounts of $\mathrm{Hg}$ (in the range of $500-550 \mu \mathrm{g} \mathrm{Hg} \mathrm{g}^{-1} \mathrm{DW}$ ) independently of the $\mathrm{P}$ concentration supplied to the plants. Cluster roots accumulated the largest amounts of $\mathrm{Hg}$. The values ranged from 1150 to $1300 \mu \mathrm{g} \mathrm{Hg} \mathrm{g}^{-1} \mathrm{DW}$. There were no significant differences between $\mathrm{P}$ treatments. $\mathrm{Hg}$ accumulation was significantly higher in cluster roots than in roots or nodules (Figure 7). In summary, plants accumulated large concentrations of $\mathrm{Hg}$ in nodules, roots and cluster roots, although not as large as plants grown in Almadén Hg-contaminated soils (Figure 5). 


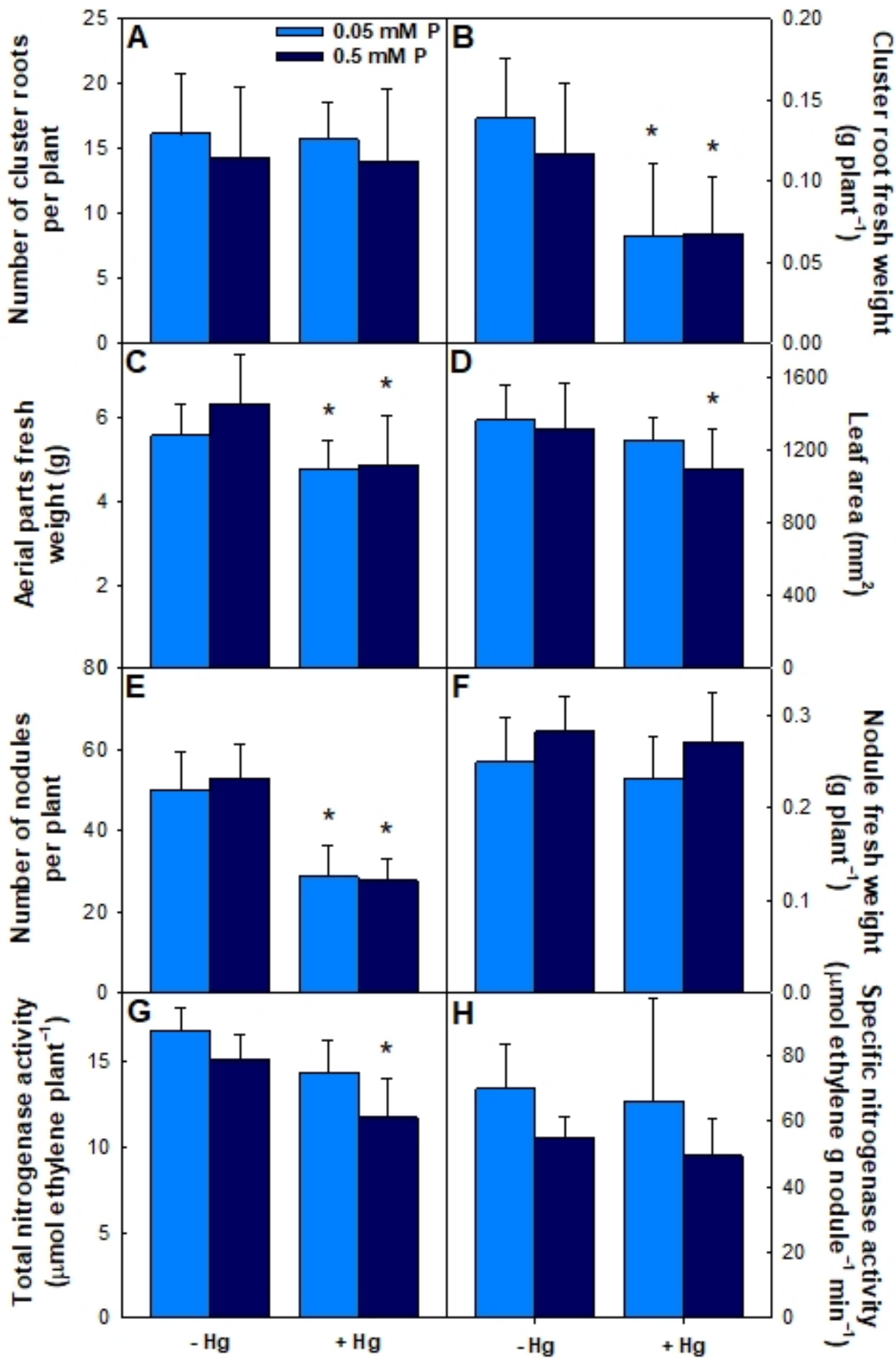

Figure 6. Effect of $\mathrm{Hg}$ on cluster roots number and weight (A,B); growth parameters (C,D); nodulation $(\mathbf{E}, \mathbf{F})$ and nitrogen fixation $(\mathbf{G}, \mathbf{H})$ in plants grown hydroponically under two $\mathrm{P}$ concentrations. L. albus cv. G1 plants were inoculated with B. canariense L-7AH. Plants were grown in vermiculite and deprived of $P$ for three weeks; then, two different $P$ concentrations $(0.05$ or $0.5 \mathrm{mM})$ were added to the nutrient solution. One half of the plants were watered with nutrient solution containing $50 \mu \mathrm{M}$ $\mathrm{HgCl}_{2}$. Means $(n=10) \pm \mathrm{SD}$ are shown. Asterisks $\left(^{*}\right)$ indicate significant differences between plants exposed to $\mathrm{Hg}$ or not. 


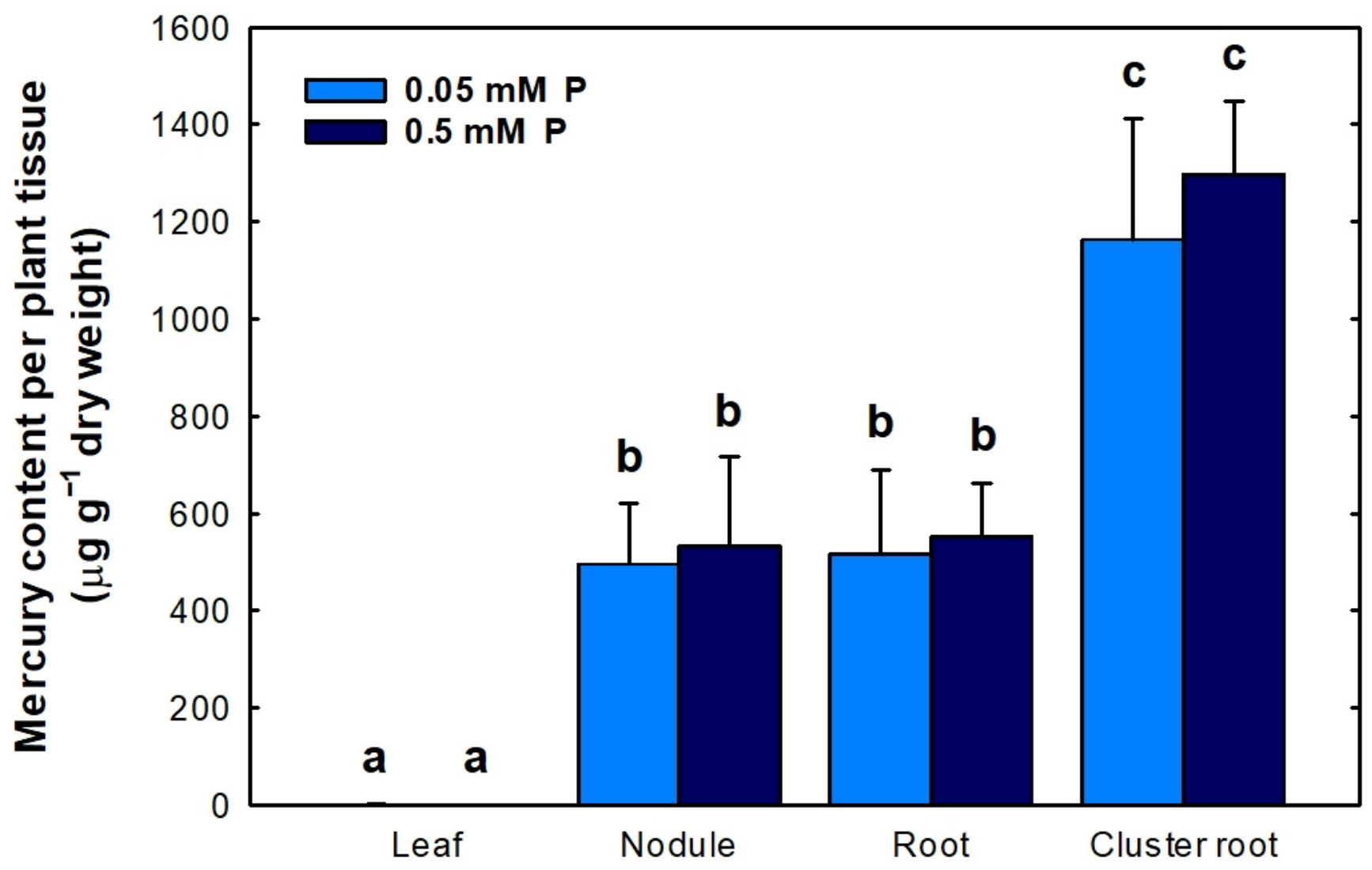

\section{Plant tissue}

Figure 7. Mercury accumulation in leaves, nodules, roots and cluster roots of L. albus G1 plants inoculated with B. canariense L-7AH and grown hydroponically, in the presence of $50 \mu \mathrm{M} \mathrm{HgCl}_{2}$. Plants were deprived of $\mathrm{P}$ for three weeks, and thereafter, two $\mathrm{P}$ concentrations $(0.05$ and $0.5 \mathrm{mM})$ were added to the nutrient solution. Means $(n=4) \pm \mathrm{SD}$ are shown. Different letters indicate significant differences.

Bioaccumulation factors were similar for nodules and roots and significantly higher for cluster roots (Table 3). The P concentration in the nutrient solution had no significant effect on BAFs. Interestingly, these values were much lower than the ones obtained for plants grown in $\mathrm{Hg}$-contaminated soils (Table 2). The bioavailable $\mathrm{Hg}$ in the substrate was $0.40 \mu \mathrm{g} \mathrm{g}^{-1}$ after 5 days, $1.35 \mu \mathrm{g} \mathrm{g}^{-1}$ after 15 days and $3.76 \mu \mathrm{g} \mathrm{g}^{-1}$ at the end of the experiment, which is higher than the values for bioavailable $\mathrm{Hg}$ in $\mathrm{AH}$ and LC soils. However, $\mathrm{Hg}$ adsorption by vermiculite has been reported [59], which could lead to lower $\mathrm{Hg}$ bioavailability and explain why plants grown in vermiculite accumulated less $\mathrm{Hg}$ than plants grown in contaminated Almadén soils, and presented lower BAFs.

Table 3. Mercury bioaccumulation factors (BAF) of nodules, roots and cluster roots of L. albus G1 plants grown hydroponically. BAFs were calculated as the ratio between the $\mathrm{Hg}$ concentration in the organ tissue and the bioavailable $\mathrm{Hg}$ concentration in the substrate. Means $\pm \mathrm{SD}$ are shown.

\begin{tabular}{ccc}
\hline Tissue & $\mathbf{0 . 0 5} \mathbf{~ m M ~ P}$ & $\mathbf{0 . 5} \mathbf{~ m M ~ P ~}$ \\
\hline Nodules & $131.9 \pm 33$ & $142 \pm 48.5$ \\
Roots & $137.4 \pm 45.7$ & $146.8 \pm 29.7$ \\
Cluster roots & $309.4 \pm 66.1$ & $345 \pm 40.2$ \\
\hline
\end{tabular}

\section{Discussion}

Lupinus albus cv. G1 plants cultivated hydroponically in symbiosis with Hg-resistant Bradyrhizobium canariense L-7AH can tolerate large $\mathrm{Hg}$ doses and grow normally, and ac- 
cumulate significant $\mathrm{Hg}$ amounts in their roots and nodules [35,36]. Moreover, L. albus cv. Marta plants have also been shown to endure growth in Hg-contaminated substrates [13,60]. The purpose of the present study was to evaluate L. albus cv. G1 and N1 growth in $\mathrm{Hg}$ contaminated soils from the Almadén Mining District (Ciudad Real, Spain), and assess their phytoremediation potential. Two soils from the area were selected. The soil from Almadenejos (AH) contained 21,845 $\mu \mathrm{g} \mathrm{g}^{-1} \mathrm{Hg}$ (Table 1), among the highest concentrations ever reported. Previous studies showed a mean $\mathrm{Hg}$ concentration in the soils of Almadenejos of $4220 \mu \mathrm{g} \mathrm{g}^{-1}$ with a maximum of $15,900 \mu \mathrm{g} \mathrm{g}^{-1}$, making it one of the most contaminated sites in the world [61]. Most $\mathrm{Hg}$ was in the form of cinnabar, and only $0.01 \%\left(2.69 \mu \mathrm{g} \mathrm{g}^{-1}\right)$ was bioavailable, probably due to the $\mathrm{pH}$ of the soil, which was very close to neutrality. The second soil (LC) collected from Las Cuevas contained less $\mathrm{Hg}$ $\left(2622 \mu \mathrm{g} \mathrm{g}^{-1}\right)$, but due to the acidic $\mathrm{pH}$ of this soil, bioavailable $\mathrm{Hg}$ was comparatively higher $\left(0.82 \mu \mathrm{g} \mathrm{g}^{-1}\right)$. L. albus plants inoculated with B. canariense L-7AH, or non-inoculated, were able to grow normally in both soils. All plants exhibited similar sizes, leaf color and area, chlorophyll content, stomatal conductance and nitrogenase activity. The fact that non-inoculated plants were able to develop nodules and fix nitrogen proved that both soils contained native functional $\mathrm{Hg}$-tolerant rhizobia capable of establishing efficient symbiosis with L. albus. In fact, B. canariense L-7AH was isolated from Almadenejos soil [55].

The emergence of numerous cluster roots in plants grown in both Hg-contaminated soils was most likely related to their low P content, and in accordance with previous knowledge [27,30]. Iron deficiency might also trigger the formation of cluster roots [28]. However, our analyses revealed that both soils were quite rich in bioavailable $\mathrm{Fe}$, and therefore, this possibility may be discarded. L. albus cluster roots are well known to excrete large amounts of organic acid anions, mainly citrate and malate. Up to $9 \mathrm{mM}$ citrate has been measured in the rhizosphere of this species [62]. The release of organic acid anions leads to soil acidification and mobilization of $\mathrm{P}$ and other nutrients, but also toxic heavy metals $[30,63]$. Organic acid anions also increase dissolved organic matter originated from soil organic matter [64]. Soil organic matter significantly limits the bioavailability of $\mathrm{Hg}$ [65]. However, $\mathrm{Hg}$ binding to organic matter declines when the $\mathrm{pH}$ decreases since protons compete with the heavy metal for reduced sulfur sites [66]. Most likely, L. albus plants grown in $\mathrm{Hg}$-contaminated soils from Almadenejos and Las Cuevas were able to mobilize certain amounts of $\mathrm{Hg}$. It has also been shown that dissolved organic matter leads to the release of $\mathrm{Hg}$ from cinnabar $(\mathrm{HgS})$, increasing its bioavailability [67].

To test whether cluster roots played a role in $\mathrm{Hg}$ uptake and accumulation by lupin plants, a strategy was devised to promote the development of cluster roots in L. albus cv. G1 plants inoculated with Hg-resistant B. canariense strain L-7AH. The approach was successful and all plants developed cluster roots, although the weight of cluster roots was lower when plants were grown in the presence of $\mathrm{Hg}$. Plants were healthy and flowering after six weeks of growth in the presence or absence of $\mathrm{Hg}$, and comparable to plants that were not deprived of $\mathrm{P}$ [35], thus suggesting that the cluster roots-promoting conditions used were not detrimental for plant development.

L. albus cv. G1 and cv. N1 plants in symbiosis with B. canariense L-7AH were able to accumulate large amounts of $\mathrm{Hg}$ in nodules, roots and cluster roots both when grown in $\mathrm{Hg}$-contaminated soils and when grown in vermiculite in the presence of $\mathrm{HgCl}_{2}$. Under both growth conditions, plants were unable to translocate the heavy metal to their aerial parts and $\mathrm{Hg}$ was absent from leaves and seeds. L. albus cv. Marta plants have been reported to translocate very small amounts of $\mathrm{Hg}$ to the aerial parts $[13,60]$. A very small $\mathrm{Hg}$ accumulation was observed in the leaves of L. albus cv. G1 plants inoculated with $B$. canariense L-7AH when grown in vermiculite in the presence of different concentrations of $\mathrm{Hg}$ under growth conditions that did not induce the formation of cluster roots [35]. Lupin cluster roots might be responsible for $\mathrm{Hg}$ phytostabilization in such a manner that translocation to the aerial parts of the plant is blocked.

Nodules of plants grown in the highly $\mathrm{Hg}$-contaminated $\mathrm{AH}$ soil or in vermiculite accumulated similar amounts of the heavy metal, while nodules of plants grown in LC soil 
accumulated less Hg. The latter presented a significantly lower number of nodules [57], which suggested that some soil properties might partially inhibit root nodulation. It has been long known that acidic soil pH negatively affects nodulation in many legumes [68-70], so the low $\mathrm{pH}$ (5.09) of the LC soil might be responsible for the above-mentioned decrease in nodulation.

$\mathrm{Hg}$ accumulation in the roots of plants grown in $\mathrm{AH}$ soil was significantly higher than $\mathrm{Hg}$ accumulation in the roots of plants grown in LC soil or than that in roots of plants grown in vermiculite. These differences match the differences in bioavailable $\mathrm{Hg}$ concentration between the two soils and the $\mathrm{Hg}$ concentration used for the hydroponic experiments, which was designed to be somewhere in the middle. $\mathrm{Hg}$ accumulation in cluster roots of plants grown in vermiculite under cluster root-promoting conditions was higher than in roots and nodules. Interestingly, $\mathrm{Hg}$ contents in nodules and roots was only slightly higher than that previously reported [35] for plants with no cluster roots. This seems to suggest that the $\mathrm{Hg}$ accumulated in cluster roots might not be transferred to other belowground organs.

The accumulation of $\mathrm{Hg}$ in the cluster roots of plants grown in $\mathrm{AH}$ soil was extraordinarily high, while in cluster roots from plants grown in LC soil or vermiculite the values were somewhat lower. $\mathrm{Hg}$ concentrations in roots and nodules are much higher than those previously published for roots of L. albus cv. Marta [13,60,71], eggplant [72], lavender [73], barley [74], rice [75], mung bean [34], olive tree [76] or many other plant species ([52] and references therein). Some ferns have been reported to accumulate very high $\mathrm{Hg}$ concentration in roots, and Nephrolepis exaltata has been proposed as a potential $\mathrm{Hg}$ rhizostabilizer [77]. Plants from different species have been shown to accumulate $\mathrm{Hg}$ in different tissues, but the uptake mechanism by roots is unknown. No precise membrane transporters involved in root $\mathrm{Hg}^{2+}$ uptake have been identified to date. Because of the similarities between $\mathrm{Cd}$ and $\mathrm{Hg}$, it is possible that specific transmembrane $\mathrm{Cd}$ transporters [78] might be used for $\mathrm{Hg}$ entrance [52]. The bioaccumulation of $\mathrm{Hg}$ in the aquatic plant Elodea nuttallii has been analyzed, concluding that copper transporters might be involved in the process [79]. Numerous metal transporter homologues have been identified in white lupin roots [80]. Whether $\mathrm{Cu}$ or $\mathrm{Cd}$ transporters might play a similar role in the uptake of $\mathrm{Hg}$ by L. albus remains to be proven, but if this were the case, cluster roots, because of their very large surface, would likely play a significant role in increasing the uptake and concentration of $\mathrm{Hg}$.

In bacteria, several $\mathrm{Hg}$ transporters have been characterized [81]. Transformation of Arabidopsis thaliana plants with the MerC $\mathrm{Hg}$ transporter resulted in enhanced $\mathrm{Hg}$ accumulation [82], but did not provide clues as to how plants take this heavy metal up. Recently, we reported that rhizobia can effectively detoxify $\mathrm{Hg}$ by reducing $\mathrm{Hg}^{2+}$ to $\mathrm{Hg}^{0}$. However, in the case of B. canariense, additional mechanisms that might involve $\mathrm{Hg}$ immobilization appear to be involved [83].

The mechanisms to sequester $\mathrm{Hg}$ in L. albus belowground organs have not yet been elucidated. However, hypotheses can be formulated based on different evidence. White lupin cluster roots are rich in malate and succinate that are secreted to the rhizosphere. These organic acids can also chelate heavy metals inside the root cell, and such chelates are primarily located in the vacuole. This has been reported to occur in several hyperaccumulators such as Thlaspi caerulescens and Arabidopsis halleri $[84,85]$. The presence of Se in the soil might lead to the formation of HgSe insoluble complexes in the rhizosphere and/or the roots that immobilize $\mathrm{Hg}$ and inhibit both uptake and translocation [86,87]. Thiols and phenolics concentrations have been reported to increase in L. albus cv. Marta when grown in the presence of $\mathrm{Hg}$ [88]. Exposure to $\mathrm{Hg}$ induces production of cysteine (Cys) and glutathione (GSH) in different plants, including the metallophyte Sylene vulgaris [89]. Phytochelatins (PCs) are Cys-rich peptides assembled from GSH units, and they form covalent bonds with $\mathrm{Hg}^{2+}$. Complexation of $\mathrm{Hg}$ with PCs has been reported to be important for plant $\mathrm{Hg}$ tolerance [90]. $\mathrm{Hg}^{2+}$ can also be ligated to sulfur-rich structural proteins in the cell wall, such as extensins and expansins [91]. Conglutin gamma, an 
oligomeric glycoprotein that is abundant in L. albus seeds and seedling roots, is capable of aggregating and precipitating $\mathrm{Hg}$ [92], but its presence in adult roots or cluster roots has not been reported to date.

\section{Conclusions}

Phytostabilization aims to contain contaminants within the vadose zone of soils through immobilization in the soil or in the root system [93], thus preventing contaminants from migration to other sites due to erosion (wind and water), leaching or dispersion. An important advantage of phytosequestration by roots, or rhizosequestration, is that it does not generate a contaminated secondary waste that needs further treatment as phytoextraction does, favors ecosystem development and enhances biodiversity [93]. Furthermore, accumulation and immobilization of toxic elements in the roots of agricultural plants does not hinder the use of the aerial parts (stems, leaves, fruits, seeds) for food or feed. Our results indicate that $L$. albus plants in symbiosis with $B$. canariense accumulate extremely large amounts of $\mathrm{Hg}$ in their nodules, roots and particularly in cluster roots without translocation to the aerial part. They efficiently remove $\mathrm{Hg}$ from the soils and immobilize the metal in their underground tissues, thus reducing its bioavailability and dispersal. This trait, together with the plant's ability to establish symbiosis with soil rhizobia and fix atmospheric $\mathrm{N}_{2}$, its Fe mobilizing capacity and its adaptability to $\mathrm{P}$ deprived soils, make white lupin a suitable candidate for revegetation of $\mathrm{Hg}$-contaminated soils. The extreme bioaccumulation factors of $L$. albus plants in nodules, roots and especially in cluster roots suggest that it may constitute a useful system to investigate the mechanisms of $\mathrm{Hg}$ uptake and immobilization in plant roots, and a powerful phytoremediation tool with promising potential in $\mathrm{Hg}$-contaminated soils.

Supplementary Materials: The following are available online at https:/ /www.mdpi.com/article/10 .3390 /horticulturae7090302/s1, Table S1: Effect of the fixed factors soil, cultivar and inoculation, and their interactions on the different parameters, analyzed by factorial ANOVA $(p \leq 0.05)$. Asterisks $\left(^{*}\right)$ denote significant effects. Table S2: Effect of the fixed factors $\mathrm{Hg}$ treatment and P concentration, and their interactions on the different parameters analyzed by factorial ANOVA $(p \leq 0.05)$. Asterisks $\left(^{*}\right)$ denote significant effects.

Author Contributions: Conceptualization, M.A.Q., M.F.P., M.M.L. and J.J.P.; methodology, M.A.Q. and S.F.; validation, M.A.Q. and S.F.; formal analysis, M.A.Q. and J.J.P.; investigation, M.A.Q. and S.F.; resources, M.A.Q., M.M.L. and J.J.P.; writing—original draft preparation, M.A.Q.; writing—review and editing, M.A.Q., M.M.L. and J.J.P.; visualization, M.A.Q. and J.J.P; supervision, M.A.Q. and J.J.P.; project administration, M.A.Q.; funding acquisition, M.M.L. and J.J.P. All authors have read and agreed to the published version of the manuscript.

Funding: This research was funded by Agencia Estatal de Investigación, AEI, Spain, grant number AGL2017-88381-R, and by Agencia Estatal Consejo Superior de Investigaciones Científicas, CSIC, grant number 2016SU0005.

Institutional Review Board Statement: Not applicable.

Informed Consent Statement: Not applicable.

Data Availability Statement: Data are available from the authors upon reasonable request.

Acknowledgments: The authors thank Miguel A. López-Berdonces, José M. Esbrí and Pablo L. Higueras from the Heavy Metals Biogeochemistry Laboratory of the School of Mining and Industrial Engineering of Almadén for their help with the soil collection and analyses. We also thank CICYTEX (Centro de Investigaciones Científicas y Tecnológicas de Extremadura), Finca La Orden-Valdesequera (Badajoz, Spain) for their generous gift of the seeds used in this work.

Conflicts of Interest: The authors declare no conflict of interest.

\section{References}

1. Brevik, E.C.; Steffan, J.J.; Rodrigo-Comino, J.; Neubert, D.; Burgess, L.C.; Cerdà, A. Connecting the public with soil to improve human health. Environ. J. Soil Sci. 2019, 70, 898-910. [CrossRef] 
2. Amundson, R.; Berhe, A.A.; Hopmans, J.W.; Olson, C.; Sztein, A.E.; Sparks, D.L. Soil and human security in the 21st century. Science 2015, 348, 1261071. [CrossRef] [PubMed]

3. Alengebawy, A.; Abdelkhalek, S.T.; Qureshi, S.R.; Wang, M.-Q. Heavy metals and pesticides toxicity in agricultural soil and plants: Ecological risks and human health implications. Toxics 2021, 9, 42. [CrossRef]

4. Gao, Y.; Jia, J.; Xi, B.; Tan, W. Divergent response of heavy metal bioavailability in soil rhizosphere to agricultural land use change from paddy fields to various drylands. Environ. Sci. Process. Impacts 2021, 23, 417-428. [CrossRef] [PubMed]

5. Boening, D.W. Ecological effects, transport, and fate of mercury: A general review. Chemosphere 2000, 40, 1335-1351. [CrossRef]

6. Molina, J.A.; Oyarzun, R.; Esbrí, J.M.; Higueras, P. Mercury accumulation in soils and plants in the Almadén Mining District, Spain: One of the most contaminated sites on Earth. Environ. Geochem. Health 2006, 28, 487-498. [CrossRef] [PubMed]

7. Patra, M.; Sharma, A. Mercury toxicity in plants. Bot. Rev. 2000, 66, 379-422. [CrossRef]

8. Desauziers, V.; Castre, N.; Cloirec, P.L. Sorption of methylmercury by clays and mineral oxides. Environ. Technol. 1997, 18, 1009-1018. [CrossRef]

9. Millán, R.; Gamarra, R.; Schmid, T.; Sierra, M.J.; Quejido, A.J.; Sánchez, D.M.; Cardona, A.I.; Fernández, M.; Vera, R. Mercury content in vegetation and soils of the Almadén Mining Area (Spain). Sci. Total Environ. 2006, 368, 79-87. [CrossRef] [PubMed]

10. $\mathrm{Xu}$, J.; Kleja, D.B.; Biester, H.; Lagerkvist, A.; Kumpiene, J. Influence of particle size distribution, organic carbon, $\mathrm{pH}$ and chlorides on washing of mercury contaminated soil. Chemosphere 2014, 109, 99-105. [CrossRef] [PubMed]

11. Higueras, P.; Oyarzun, R.; Biester, H.; Lillo, J.; Lorenzo, S. A first insight into mercury distribution and speciation in soils from the Almadén Mining District, Spain. J. Geochem. Explor. 2003, 80, 95-104. [CrossRef]

12. Higueras, P.; Oyarzun, R.; Lillo, J.; Sánchez-Hernández, J.C.; Molina, J.A.; Esbrí, J.M.; Lorenzo, S. The Almadén District (Spain): Anatomy of one of the world's largest Hg-contaminated sites. Sci. Total Environ. 2006, 356, 112-124. [CrossRef] [PubMed]

13. Zornoza, P.; Millán, R.; Sierra, M.J.; Seco, A.; Esteban, E. Efficiency of white lupin in the removal of mercury from contaminated soils: Soil and hydroponic experiments. J. Environ. Sci. 2010, 22, 421-427. [CrossRef]

14. de la Peña, T.C.; Pueyo, J.J. Legumes in the reclamation of marginal soils, from cultivar and inoculant selection to transgenic approaches. Agron. Sustain. Dev. 2012, 32, 65-91. [CrossRef]

15. Frérot, H.; Lefèbvre, C.; Gruber, W.; Collin, C.; Dos Santos, A.; Escarré, J. Specific interactions between local metallicolous plants improve the phytostabilization of mine soils. Plant. Soil 2006, 282, 53-65. [CrossRef]

16. Fernández-Pascual, M.; Pueyo, J.J.; de Felipe, M.R.; Golvano, M.P.; Lucas, M.M. Singular features of the Bradyrhizobium-Lupinus symbiosis. Dyn. Soil Dyn. Plant 2007, 1, 1-16.

17. Jansen, P.C.M. Lupinus albus L. Record from PROTA4U; Brink, M., Belay, G., Eds.; PROTA (Plant Resources of Tropical Africa/Ressources végétales de l'Afrique tropicale): Wageningen, The Netherlands, 2006.

18. Lucas, M.M.; Stoddard, F.L.; Annicchiarico, P.; Frías, J.; Martínez-Villaluenga, C.; Sussmann, D.; Duranti, M.; Seger, A.; Zander, P.M.; Pueyo, J.J. The future of lupin as a protein crop in Europe. Front. Plant Sci. 2015, 6, 705. [CrossRef] [PubMed]

19. De Ron, A.M.; Sparvoli, F.; Pueyo, J.J.; Bazile, D. Protein crops: Food and feed for the future. Front. Plant Sci. 2017, 8, 6-9. [CrossRef]

20. Msaddak, A.; Rey, L.; Imperial, J.; Palacios, J.M.; Mars, M.; Pueyo, J.J. Phylogenetic analyses of rhizobia isolated from nodules of Lupinus angustifolius in Northern Tunisia reveal Devosia sp. as a new microsymbiont of lupin species. Agronomy 2021, 11, 1510. [CrossRef]

21. de la Peña, T.C.; Fedorova, E.; Pueyo, J.J.; Lucas, M.M. The symbiosome: Legume and rhizobia co-evolution toward a nitrogenfixing organelle? Front. Plant Sci. 2018, 8, 2229. [CrossRef] [PubMed]

22. González-Sama, A.; Lucas, M.M.; de Felipe, M.R.; Pueyo, J.J. An unusual infection mechanism and nodule morphogenesis in white lupin (Lupinus albus). New Phytol. 2004, 163, 371-380. [CrossRef]

23. Purnell, H.M. Studies of the family Proteaceae i. Anatomy and morphology of the roots of some Victorian species. Aust. J. Bot. 1960, 8, 38-50. [CrossRef]

24. Lamont, B. Mechanisms for enhancing nutrient uptake in plants, with particular reference to Mediterranean South Africa and Western Australia. Bot. Rev. 1982, 48, 597-689. [CrossRef]

25. Marschner, H.; Römheld, V.; Horst, W.J.; Martin, P. Root-induced changes in the rhizosphere: Importance for the mineral nutrition of plants. Z. Pflanz. Und Bodenkd 1986, 149, 441-456. [CrossRef]

26. Neumann, G.; Martinoia, E. Cluster roots-An underground adaptation for survival in extreme environments. Trends Plant. Sci. 2002, 7, 162-167. [CrossRef]

27. Dinkelaker, B.; Hengeler, C.; Marschner, H. Distribution and function of proteoid roots and other root clusters. Bot. Acta 1995, 108, 183-200. [CrossRef]

28. Arahou, M.; Diem, H.G. Iron deficiency induces cluster (proteoid) root formation in Casuarina glauca. Plant Soil 1997, 196, 71-79. [CrossRef]

29. Gerke, J.; Römer, W.; Jungk, A. The excretion of citric and malic acid by proteoid roots of Lupinus albus L.; Effects on soil solution concentrations of phosphate, iron, and aluminum in the proteoid rhizosphere in samples of an oxisol and a luvisol. Z. Pflanz. Und Bodenkd 1994, 157, 289-294. [CrossRef]

30. Lamont, B. Structure, ecology and physiology of root clusters-A review. Plant Soil 2003, 248, 1-19. [CrossRef]

31. Gilbert, G.A.; Knight, J.D.; Vance, C.P.; Allan, D.L. Acid phosphatase activity in phosphorus-deficient white lupin roots. Plant Cell Environ. 1999, 22, 801-810. [CrossRef] 
32. Liu, J.; Uhde-Stone, C.; Li, A.; Vance, C.; Allan, D. A phosphate transporter with enhanced expression in proteoid roots of white lupin (Lupinus albus L.). Plant Soil 2001, 237, 257-266. [CrossRef]

33. Pueyo, J.J.; Quiñones, M.A.; de la Peña, T.C.; Fedorova, E.E.; Lucas, M.M. Nitrogen and phosphorus interplay in lupin root nodules and cluster roots. Front. Plant Sci. 2021, 12. [CrossRef] [PubMed]

34. Mondal, N.K.; Das, C.; Datta, J.K. Effect of Mercury on Seedling Growth, Nodulation and Ultrastructural Deformation of Vigna Radiata (L) Wilczek. Environ. Monit. Assess. 2015, 187, 241. [CrossRef] [PubMed]

35. Quiñones, M.A.; Ruiz-Díez, B.; Fajardo, S.; López-Berdonces, M.A.; Higueras, P.L.; Fernández-Pascual, M. Lupinus albus plants acquire mercury tolerance when inoculated with an Hg-resistant Bradyrhizobium strain. Plant Physiol. Biochem. 2013, 73, 168-175. [CrossRef] [PubMed]

36. Ruiz-Díez, B.; Quiñones, M.A.; Fajardo, S.; Morcillo, C.; Fernández-Pascual, M. Possible reasons for tolerance to mercury of Lupinus albus cv. G1 inoculated with Hg-resistant and sensitive Bradyrhizobium canariense strains. Symbiosis 2015, 67, 91-102. [CrossRef]

37. de Lorenzo, C.A.; Fernández-Pascual, M.M.; de Felipe, M.R. Protective enzymes against active oxygen species during nitrateinduced senescence of Lupinus albus nodules. J. Plant Physiol. 1994, 144, 633-640. [CrossRef]

38. Fernández-Pascual, M.; de Lorenzo, C.; de Felipe, M.R.; Rajalakshmi, S.; Gordon, A.J.; Thomas, B.J.; Minchin, F.R. Possible reasons for relative salt stress tolerance in nodules of white lupin cv. Multolupa. J. Exp. Bot. 1996, 47, 1709-1716. [CrossRef]

39. Pastor, J.; Hernández, A.J.; Prieto, N.; Fernández-Pascual, M. Accumulating behaviour of Lupinus albus L. growing in a normal and a decalcified calcic luvisol polluted with Zn. J. Plant Physiol. 2003, 160, 1457-1465. [CrossRef] [PubMed]

40. Zornoza, P.; Vázquez, S.; Esteban, E.; Fernández-Pascual, M.; Carpena, R. Cadmium-stress in nodulated white lupin: Strategies to avoid toxicity. Plant Physiol. Biochem. 2002, 40, 1003-1009. [CrossRef]

41. Sánchez-Pardo, B.; Fernández-Pascual, M.; Zornoza, P. Copper microlocalisation, ultrastructural alterations and antioxidant responses in the nodules of white lupin and soybean plants grown under conditions of copper excess. Environ. Exp. Bot. 2012, 84, 52-60. [CrossRef]

42. Stephenson, C.; Black, C.R. One step forward, two steps back: The evolution of phytoremediation into commercial technologies. Biosci. Horiz. 2014, 7, 1-15. [CrossRef]

43. Yang, X.; Feng, Y.; He, Z.; Stoffella, P.J. Molecular mechanisms of heavy metal hyperaccumulation and phytoremediation. J. Trace Elem. Med. Biol. 2005, 18, 339-353. [CrossRef] [PubMed]

44. Saravanan, A.; Jeevanantham, S.; Narayanan, V.A.; Kumar, P.S.; Yaashikaa, P.R.; Muthu, C.M.M. Rhizoremediation-A promising tool for the removal of soil contaminants: A review. J. Environ. Chem. Eng. 2020, 8, 103543. [CrossRef]

45. Dary, M.; Chamber-Pérez, M.A.; Palomares, A.J.; Pajuelo, E. "In situ” phytostabilisation of heavy metal polluted soils using Lupinus luteus inoculated with metal resistant plant-growth promoting rhizobacteria. J. Hazard. Mater. 2010, 177, 323-330. [CrossRef]

46. Corso, M.; de la Torre, V.S.G. Biomolecular approaches to understanding metal tolerance and hyperaccumulation in plants. Metallomics 2020, 12, 840-859. [CrossRef] [PubMed]

47. Krämer, U. Metal hyperaccumulation in plants. Annu. Rev. Plant. Biol. 2010, 61, 517-534. [CrossRef]

48. Reeves, R.D.; van der Ent, A.; Baker, A.J.M. Global distribution and ecology of hyperaccumulator plants. In Agromining: Farming for Metals, Mineral. Resource Reviews; Springer: Cham, Switerland, 2018; pp. 75-92.

49. Romero-Hernández, J.A.; Amaya-Chávez, A.; Balderas-Hernández, P.; Roa-Morales, G.; González-Rivas, N.; Balderas-Plata, M.Á. Tolerance and hyperaccumulation of a mixture of heavy metals $(\mathrm{Cu}, \mathrm{Pb}, \mathrm{Hg}$, and $\mathrm{Zn})$ by four aquatic macrophytes. Int. J. Phytoremediation 2017, 19, 239-245. [CrossRef] [PubMed]

50. Rascio, N.; Navari-Izzo, F. Heavy metal hyperaccumulating plants: How and why do they do it? And what makes them so interesting? Plant. Sci. 2011, 180, 169-181. [CrossRef] [PubMed]

51. Suman, J.; Uhlik, O.; Viktorova, J.; Macek, T. Phytoextraction of heavy metals: A promising tool for clean-up of polluted environment? Front. Plant Sci. 2018, 9, 1476. [CrossRef] [PubMed]

52. Tiodar, E.D.; Văcar, C.L.; Podar, D. Phytoremediation and microorganisms-assisted phytoremediation of mercury-contaminated soils: Challenges and perspectives. Int. J. Environ. Res. Public Health 2021, 18, 2435. [CrossRef] [PubMed]

53. de la Torre, V.S.G.; de la Peña, T.C.; Lucas, M.M.; Pueyo, J.J. Rapid screening of Medicago truncatula germplasm for mercury tolerance at the seedling stage. Environ. Exp. Bot. 2013, 91, 90-96. [CrossRef]

54. de la Torre, V.S.G.; de la Peña, T.C.; Pueyo, J.J.; Lucas, M.M. Cadmium-tolerant and -sensitive cultivars identified by screening of Medicago truncatula germplasm display contrasting responses to cadmium stress. Front. Plant Sci. 2021, 12, 293.

55. Ruiz-Díez, B.; Quiñones, M.A.; Fajardo, S.; López, M.A.; Higueras, P.; Fernández-Pascual, M. Mercury-resistant rhizobial bacteria isolated from nodules of leguminous plants growing in high Hg-contaminated soils. Appl. Microbiol. Biotechnol. 2012, 96, 543-554. [CrossRef] [PubMed]

56. Ruiz-Díez, B.; Fajardo, S.; Puertas-Mejía, M.A.; de Felipe, M.R.; Fernández-Pascual, M. Stress tolerance, genetic analysis and symbiotic properties of root-nodulating bacteria isolated from Mediterranean leguminous shrubs in Central Spain. Arch. Microbiol. 2009, 191, 35-46. [CrossRef]

57. Quiñones, M.A.; Fajardo, S.; Rodríguez-Caviedes, L.; Hortigüela, C.; Contreras, M.; Lucas, M.M.; Pueyo, J.J.; Fernández-Pascual, M. Mercury tolerance of white lupin growing in soils of the Almadén Mining District. In Current and Future Trends in Mercury Research; Chartridge Books Oxford: Oxford, UK, 2018; pp. 31-39. 
58. Millán, R.; Lominchar, M.A.; López-Tejedor, I.; Rodríguez-Alonso, J.; Schmid, T.; Sierra, M.J. Behavior of mercury in the Valdeazogues riverbank soil and transfer to Nerium oleander L. J. Geochem. Explor. 2012, 123, 136-142. [CrossRef]

59. Brigatti, M.F.; Colonna, S.; Malferrari, D.; Medici, L.; Poppi, L. Mercury adsorption by montmorillonite and vermiculite: A combined XRD, TG-MS, and EXAFS study. Appl. Clay Sci. 2005, 28, 1-8. [CrossRef]

60. Millán, R.; Esteban, E.; Zornoza, P.; Sierra, M.J. Could an abandoned mercury mine area be cropped? Environ. Res. 2013, $125,150-159$.

61. Martínez-Coronado, A.; Oyarzun, R.; Esbrí, J.M.; Llanos, W.; Higueras, P. Sampling high to extremely high Hg concentrations at the Cerco de Almadenejos, Almadén Mining District (Spain): The old metallurgical precinct (1794 to 1861AD) and surrounding areas. J. Geochem. Explor. 2011, 109, 70-77. [CrossRef]

62. Dessureault-Rompré, J.; Nowack, B.; Schulin, R.; Luster, J. Spatial and temporal variation in organic acid anion exudation and nutrient anion uptake in the rhizosphere of Lupinus albus L. Plant Soil 2007, 301, 123-134. [CrossRef]

63. Dessureault-Rompré, J.; Nowack, B.; Schulin, R.; Tercier-Waeber, M.L.; Luster, J. Metal solubility and speciation in the rhizosphere of Lupinus albus cluster roots. Environ. Sci. Technol. 2008, 42, 7146-7151. [CrossRef]

64. Yang, Y.; Ratté, D.; Smets, B.F.; Pignatello, J.J.; Grasso, D. Mobilization of soil organic matter by complexing agents and implications for polycyclic aromatic hydrocarbon desorption. Chemosphere 2001, 43, 1013-1021. [CrossRef]

65. He, M.; Tian, L.; Braaten, H.F.V.; Wu, Q.; Luo, J.; Cai, L.M.; Meng, J.H.; Lin, Y. Mercury-organic matter interactions in soils and sediments: Angel or devil? Bull. Environ. Contam. Toxicol. 2019, 102, 621-627. [CrossRef]

66. Haitzer, M.; Aiken, G.R.; Ryan, J.N. Binding of mercury (II) to aquatic humic substances: Influence of $\mathrm{pH}$ and source of humic substances. Environ. Sci. Technol. 2003, 37, 2436-2441. [CrossRef]

67. Ravichandran, M.; Aiken, G.R.; Reddy, M.M.; Ryan, J.N. Enhanced dissolution of cinnabar (mercuric sulfide) by dissolved organic matter isolated from the Florida Everglades. Environ. Sci. Technol. 1998, 32, 3305-3311. [CrossRef]

68. Angelini, J.; Taurian, T.; Morgante, C.; Ibáñez, F.; Castro, S.; Fabra, A. Peanut nodulation kinetics in response to low pH. Plant Physiol. Biochem. 2005, 43, 754-759. [CrossRef] [PubMed]

69. Denton, M.D.; Hill, C.R.; Bellotti, W.D.; Coventry, D.R. Nodulation of Medicago truncatula and Medicago polymorpha in two pastures of contrasting soil $\mathrm{pH}$ and rhizobial populations. Appl. Soil Ecol. 2007, 35, 441-448. [CrossRef]

70. Ferreira, T.C.; Aguilar, J.V.; Souza, L.A.; Justino, G.C.; Aguiar, L.F.; Camargos, L.S. pH effects on nodulation and biological nitrogen fixation in Calopogonium mucunoides. Rev. Bras. Bot. 2016, 39, 1015-1020. [CrossRef]

71. Rodriguez, L.; Rincón, J.; Asencio, I.; Rodríguez-Castellanos, L. Capability of selected crop plants for shoot mercury accumulation from polluted soils: Phytoremediation perspectives. Int. J. Phytoremediation 2007, 9, 1-13. [CrossRef]

72. Sierra, M.J.; Millán, R.; Esteban, E. Potential use of Solanum melongena in agricultural areas with high mercury background concentrations. Food Chem. Toxicol. 2008, 46, 2143-2149. [CrossRef] [PubMed]

73. Sierra, M.J.; Millán, R.; Esteban, E. Mercury uptake and distribution in Lavandula stoechas plants grown in soil from Almadén Mining District (Spain). Food Chem. Toxicol. 2009, 47, 2761-2767. [CrossRef] [PubMed]

74. Sierra, M.J.; Millán, R.; Cardona, A.I.; Schmid, T. Potential cultivation of Hordeum vulgare L. in soils with high mercury background concentrations. Int. J. Phytoremediat. 2011, 13, 765-778. [CrossRef] [PubMed]

75. Meng, B.; Feng, X.; Qiu, G.; Anderson, C.W.N.; Wang, J.; Zhao, L. Localization and speciation of mercury in brown rice with implications for Pan-Asian public health. Environ. Sci. Technol. 2014, 48, 7974-7981. [CrossRef]

76. Higueras, P.L.; Amorós, J.; Esbrí, J.M.; de los Reyes, C.P.; López-Berdonces, M.A.; García-Navarro, F.J. Mercury transfer from soil to olive trees. A comparison of three different contaminated sites. Environ. Sci. Pollut. Res. 2016, 23, 6055-6061. [CrossRef]

77. Chen, J.; Shiyab, S.; Han, F.X.; Monts, D.L.; Waggoner, C.A.; Yang, Z.; Su, Y. Bioaccumulation and physiological effects of mercury in Pteris vittata and Nephrolepis exaltata. Ecotoxicology 2009, 18, 110-121. [CrossRef] [PubMed]

78. Lombi, E.; Zhao, F.J.; McGrath, S.P.; Young, S.D.; Sacchi, G.A. Physiological evidence for a high-affinity cadmium transporter highly expressed in a Thlaspi caerulescens ecotype. New Phytol. 2001, 149, 53-60. [CrossRef] [PubMed]

79. Regier, N.; Larras, F.; Bravo, A.G.; Ungureanu, V.G.; Amouroux, D.; Cosio, C. Mercury bioaccumulation in the aquatic plant Elodea nuttallii in the field and in microcosm: Accumulation in shoots from the water might involve copper transporters. Chemosphere 2013, 90, 595-602. [CrossRef] [PubMed]

80. Tian, L.; Peel, G.J.; Lei, Z.; Aziz, N.; Dai, X.; He, J.; Watson, B.; Zhao, P.X.; Sumner, L.W.; Dixon, R.A. Transcript and proteomic analysis of developing white lupin (Lupinus albus L.) roots. BMC Plant Biol. 2009, 9, 1. [CrossRef]

81. Boyd, E.S.; Barkay, T. The mercury resistance operon: From an origin in a geothermal environment to an efficient detoxification machine. Front. Microbiol. 2012, 3, 349. [CrossRef]

82. Uraguchi, S.; Sone, Y.; Yoshikawa, A.; Tanabe, M.; Sato, H.; Otsuka, Y.; Nakamura, R.; Takanezawa, Y.; Kiyono, M. SCARECROW promoter-driven expression of a bacterial mercury transporter MerC in root endodermal cells enhances mercury accumulation in Arabidopsis shoots. Planta 2019, 250, 667-674. [CrossRef]

83. Arregui, G.; Hipólito, P.; Pallol, B.; Lara-Dampier, V.; García-Rodríguez, D.; Varela, H.P.; Tavakoli Zaniani, P.; Balomenos, D.; Paape, T.; de la Peña, T.C.; et al. Mercury-tolerant Ensifer medicae strains display high mercuric reductase activity and a protective effect on nitrogen fixation in Medicago truncatula nodules under mercury stress. Front. Plant Sci. 2021, 11, 560768. [CrossRef]

84. Sarret, G.; Saumitou-Laprade, P.; Bert, V.; Proux, O.; Hazemann, J.L.; Traverse, A.; Marcus, M.A.; Manceau, A. Forms of zinc accumulated in the hyperaccumulator Arabidopsis halleri. Plant Physiol. 2002, 130, 1815-1826. [CrossRef] [PubMed] 
85. Salt, D.E.; Prince, R.C.; Baker, A.J.M.; Raskin, I.; Pickering, I.J. Zinc ligands in the metal hyperaccumulator Thlaspi caerulescens as determined using X-Ray absorption spectroscopy. Environ. Sci. Technol. 1999, 33, 713-717. [CrossRef]

86. Zhang, H.; Feng, X.; Zhu, J.; Sapkota, A.; Meng, B.; Yao, H.; Qin, H.; Larssen, T. Selenium in soil inhibits mercury uptake and translocation in rice (Oryza sativa L.). Environ. Sci. Technol. 2012, 46, 10040-10046. [CrossRef] [PubMed]

87. Tran, T.A.T.; Dinh, Q.T.; Zhou, F.; Zhai, H.; Xue, M.; Du, Z.; Bañuelos, G.S.; Liang, D. Mechanisms underlying mercury detoxification in soil-plant systems after selenium application: A review. Environ. Sci. Pollut. Res. 2021, 28, 46852-46876. [CrossRef] [PubMed]

88. Esteban, E.; Moreno, E.; Peñalosa, J.; Cabrero, J.I.; Millán, R.; Zornoza, P. Short and long-term uptake of Hg in white lupin plants: Kinetics and stress indicators. Environ. Exp. Bot. 2008, 62, 316-322. [CrossRef]

89. Sobrino-Plata, J.; Herrero, J.; Carrasco-Gil, S.; Pérez-Sanz, A.; Lobo, C.; Escobar, C.; Millán, R.; Hernández, L.E. Specific stress responses to cadmium, arsenic and mercury appear in the metallophyte Silene vulgaris when grown hydroponically. RSC Adv. 2013, 3, 4736-4744. [CrossRef]

90. Carrasco-Gil, S.; Álvarez-Fernández, A.; Sobrino-Plata, J.; Millán, R.; Carpena-Ruiz, R.O.; Leduc, D.L.; Andrews, J.C.; Abadía, J.; Hernández, L.E. Complexation of $\mathrm{Hg}$ with phytochelatins is important for plant $\mathrm{Hg}$ tolerance. Plant Cell Environ. 2011, 34, 778-791. [CrossRef] [PubMed]

91. Carrasco-Gil, S.; Siebner, H.; LeDuc, D.; Webb, M.; Millán, R.; Andrews, J.C.; Hernández, L.E. Mercury localization and speciation in plants grown hydroponically or in a natural environment. Environ. Sci. Technol. 2013, 47, 3082-3090. [CrossRef]

92. Duranti, M.; Scarafoni, A.; Di Cataldo, A.; Sessa, F. Interaction of metal ions with lupin seed conglutin $\gamma$. Phytochemistry 2001, 56, 529-533. [CrossRef]

93. Bolan, N.S.; Park, J.H.; Robinson, B.; Naidu, R.; Huh, K.Y. Phytostabilization. A green approach to contaminant containment. Adv. Agron. 2011, 112, 145-204. 